\title{
COMPARATIVE ANTIBACTERIAL ACTIVITY AND QUALITY ASSESSMENT OF ESSENTIAL OILS FROM DIFFERENT PRODUCERS AGAINST ORAL PATHOGENS
}

\author{
MONICA CRISTINA NAGY-BOTA ${ }^{1}$, STEFAN NAGY- BOTA ${ }^{2}$, BOGDAN-ANDREI SUCIU ${ }^{3}$, \\ IOANA HALMACIU ${ }^{4}$, ADRIAN MAN ${ }^{5}$, ZSUZSANNA PAP ${ }^{6}$, MONIKA KOVACS ${ }^{7}$, KLARA $^{3}$ \\ BRÎNZANIUC ${ }^{8}$
}

\author{
1,2,3,4,5,6,7,8 “George Emil Palade” University of Medicine, Pharmacy, Sciences and Technology, Târgu Mureş
}

\begin{abstract}
Keywords: $\quad$ Oregano essential oil, Black pepper essential oil, Coriander essential oil, Cinnamon essential oil, Streptococcus mutans, Enterococcus faecalis
\end{abstract}

Abstract: The aim of the study is to evaluate antibacterial properties of commercial essential oils (Oregano, Black pepper, Coriander, Cinnamon) against oral pathogens (Streptococcus mutans, Enterococcus faecalis). Nevertheless, we want to asses if the price of the essential oils (EO) which were purchased from 2 different retailers, can influence the quality of essential oil and the antimicrobial effect. Materials and methods: Essential oils from two different Producers (A-high price range, respectively B-low price range) with two opposite price ranges were purchased from local retailers. The inhibitory effect was assessed by disk diffusion. Bacterial inoculums of 0.5 McFarland units $\left(\sim 1.5 \times 10^{8} \mathrm{CFU} / \mathrm{ml}\right)$ were prepared from Streptococcus mutans Enterococcus faecalis. MullerHinton agar plates were inoculated with bacterial inoculums. Sterile paper disks with the diameter of $6 \mathrm{~mm}$ (Bioanalyse Ltd, Turkey) were dispensed on the medium surface. Five $\mu$ l of essential oils were pipetted on corresponding disks. After 10 minutes (time needed for a proper diffusion of active components), the plates were incubated in normal atmosphere at $37^{\circ} \mathrm{C}$. After 24 hours of incubation, the inhibition zone diameters (in millimeters) were read and noted in spreadsheet software, aside the average price in $€ / m l$ of essential oil. A cost-efficiency antibacterial activity index was also calculated.Results: With regard to EO from Producer A, the inhibition zone against Enteroccocus ranged from the weakest $14 \mathrm{~mm}$ ( Black pepper), 28mm(Coriander) to the strongest over 40 mm(Oregano and Cinnamon). With regard to volatile essential oils from Producer B, against the Enteroccocus, the smallest inhibition zone was observed for Coriander $(10 \mathrm{~mm})$, followed by Black pepper $(11 \mathrm{~mm})$; on the opposite side, the strongest inhibition zone presented both Oregano EO and Cinnamon EO (34 mm). Against S. mutans, the weakest inhibition zone showed Black pepper $(6 \mathrm{~mm})$, followed by Coriander EO $(12 \mathrm{~mm})$ and the strongest inhibition zone had Oregano $E O(38 \mathrm{~mm})$ and Cinnamon EO $(40 \mathrm{~mm})$. All the EO from the Producer A managed to successfully inhibit $S$. mutans growth. In both producers, Origanum vulgare EO was the most cost-efficient against E. faecalis (index=0.06 for Producer $A$ and 0.03 for Producer B). In the case of Producer A, against S.mutans the best index was seen at Coriandrum sativum EO $(0,05)$ and the weakest at Cinnamonum zeylanicum (0,14). In the case of Producer B, against E. faecalis, the lowest index was seen at Piper nigrum $(0,13)$. The same pattern was seen against $S$. mutans, the highest index had Origanum vulgare $(0,03)$ and the lowest Piper nigrum $(0,23)$ Conclusions:Most of essential oils studied from both Producers, had better antibacterial effect against $S$. mutans compared to E. faecalis.All the EO from the Producer A managed to successfully inhibit $S$. mutans growth. The high price EO had a better antimicrobial effect compared to the low price EO.The strongest antimicrobial effect against E.faecalis had the high-price Oregano and Cinnamon EO and the weakest antimicrobial effect had low-price Coriander EO. Against S. mutans, the greatest efficacy had all high-price EO, and the lowest had the low-price Black pepper EO.The high price of some EO (Piper nigrum) does not make any difference regarding the antibacterial effect. Lower price EO may be still suitable in regards of antibacterial effect if considering the associated costs, even if the effect does not reach the potency of the higher-price alternatives.

\section{INTRODUCTION}

Essential oils (EO) are compounds which are extracted from plants, they are used in aromatherapy and also as a form of alternative medicine for a long time. Their characteristic essence is given by their aromatic compounds. The volatile oils can be extracted from different parts of the plants such as flowers, roots, bark or leaves.(1,2). The antibacterial properties of volatile oils had been demonstrated in previous studies. $(3,4,5)$ Oregano essential oil is a result from the distillation of Origanum vulgare (oregano) from Laminaceae family. Oregano oil shows a variety of effects such as antiinflamatory, antifungal, antiallergic, antimicrobial and antioxidant. Its activity depends

${ }^{5}$ Corresponding author: Adrian Man, Gh. Marinescu, Nr. 38, Târgu Mureş, România, E-mail: adrian.man@umfst.ro, Phone: +40265 215551 Article received on 02.07.2020 and accepted for publication on 25.08.2020 


\section{CLINICAL ASPECTS}

on the source of the oregano, the assay method and the bacteria isolates. $(6,7,8)$ Piper nigrum (Black pepper), known as black pepper, is a member of Piperaceae family which includes over a 1000 of species. It is cultivated mainly in tropical areas, such as South India and Indonesia. It has been used in medicine for its antimicrobial effect and in food industries as herbal spice.(9) Piperine, which exist in the essential oil of the black pepper, is a bioactive constituent and it is effective in soothing muscular pains and improving respiratory infections.(10) Coriander (Coriandrum sativum) is a herbaceous annual from Apiaceae family. Its fresh or dried leaves are used as spice and as an ingredient in different type of food. The seeds of coriander are used as a condiment and in medicine for its expectorant role. Also it is used in different conditions such as stomach disorders and diarrhea. The essential oils is made from the distillation of the seeds.(11,12) Cinamon (Cinnamomum zeylanicum) is a member of Lauraceae family and it grows in South and South-East Asia. It is used in Ayurvedic medicine for its soothing effect, also for its antiinflamatory, antidiabetic, anticancer and antibacterial properties. The essential oil of cinnamon contains phenolic and poly-phenolic compounds such as cinnamaldehyde and eugenol in small amount which increases the antioxidant activity. $(13,14,15,16,17,18)$

Enteroccoci are bacteria which are present in oral cavity, vagina and gastrointestinal tract of humans and animals, are one of the most important cause of nosocomial infection. Enterococcus faecalis is the predominant human enteroccocus which in dentistry have been found to be associated with oral diseases such as dental caries, periodontitis and endodontic infections. $(19,20)$ In the etiology of dental caries, Streptococcus mutans plays an important role. It has been shown that S.mutans can be transmitted from mother to child which can open the early risk for dental caries.(21) $S$. mutans is a facultative anaerobic bacteria which is responsible for the dental plaque biofilm formation.(22)

Many antimicrobial agents have been use, during the last decades, for the prevention of dental caries. The major agent for prevention of dental caries is fluoride. Another agent, chlorhexidine has been used against $S$. mutans but its unpleasant taste determined the search for new alternative therapeutic agents against oral types of bacteria. Previous studies reported antibacterial activity of different EO against E.faecalis or $S$ mutans. $(23,24,25,26,27)$

\section{PURPOSE}

The aim of the study is to evaluate antibacterial properties of commercial essential oils (Oregano, Black pepper, Coriander, Cinnamon) against oral pathogens (Streptococcus mutans, Enterococcus faecalis). Nevertheless, we want to asses if the price of the essential oils which were purchased from 2 different retailers, can influence the quality of essential oil and the antimicrobial effect.

\section{MATERIAL AND METHOD}

Essential oils from two different Producers (A-high price range, respectively B-low price range) with two opposite price ranges were purchased from local retailers. Table no.1 shows the manufacture method and the provenance of each essential oil

Table no. 1. Essential oils used in the study and their origin

\begin{tabular}{|l|l|l|l|l|}
\hline Producer & Essential oil & $\begin{array}{l}\text { Country of } \\
\text { origin }\end{array}$ & $\begin{array}{l}\text { Extraction } \\
\text { method }\end{array}$ & Source \\
\hline \multirow{4}{*}{ A } & $\begin{array}{l}\text { Origanum } \\
\text { vulgare }\end{array}$ & Turkey & $\begin{array}{l}\text { Steam } \\
\text { Distillation }\end{array}$ & Leaf \\
\cline { 2 - 5 } & Piper nigrum & India & $\begin{array}{l}\text { Steam } \\
\text { Distillation }\end{array}$ & Fruit \\
\cline { 2 - 6 } & Coriandrum & U.S.A. & Steam & Seed \\
\hline
\end{tabular}

\begin{tabular}{|l|l|l|l|l|}
\hline \multirow{4}{*}{} & sativum & & Distillation & \\
\cline { 2 - 5 } & $\begin{array}{l}\text { Cinnamonum } \\
\text { zeylanicum }\end{array}$ & $\begin{array}{l}\text { Madagascar, } \\
\text { Indonesia }\end{array}$ & $\begin{array}{l}\text { Steam } \\
\text { Distillation }\end{array}$ & Bark \\
\hline \multirow{4}{*}{ B } & $\begin{array}{l}\text { Origanum } \\
\text { vulgare }\end{array}$ & Morocco & $\begin{array}{l}\text { Steam } \\
\text { Distillation }\end{array}$ & Leaf \\
\cline { 2 - 5 } & Piper nigrum & Madagascar & $\begin{array}{l}\text { Steam } \\
\text { Distillation }\end{array}$ & Fruit \\
& $\begin{array}{l}\text { Coriandrum } \\
\text { sativum }\end{array}$ & Hungary & $\begin{array}{l}\text { Steam } \\
\text { Distillation }\end{array}$ & Seed \\
\cline { 2 - 5 } & $\begin{array}{l}\text { Cinnamonum } \\
\text { zeylanicum }\end{array}$ & Sri Lanka & $\begin{array}{l}\text { Steam } \\
\text { Distillation }\end{array}$ & Bark \\
\hline
\end{tabular}

The chemical composition of the bioactive compounds was analysed from the official reports from the producers. The composition was detected by Gas Chromatography and was specific for the lot number of each used essential oil.

The inhibitory effect was assessed by disk diffusion. Bacterial inoculums of 0.5 McFarland units $\left(\sim 1.5 \times 10^{8}\right.$ $\mathrm{CFU} / \mathrm{ml}$ ) were prepared from a clinical isolate of Streptococcus mutans (identified by Vitek2 Compact system) and from Enterococcus faecalis ATCC29212. Muller-Hinton and MullerHinton supplemented with 5\% defibrinated sheep blood agar plates (Oxoid Ltd, UK) were inoculated with the bacterial inoculums. Sterile paper disks with the diameter of $6 \mathrm{~mm}$ (Bioanalyse Ltd, Turkey) were dispensed on the medium surface. Five $\mu 1$ of essential oils were pipetted on corresponding disks. After 10 minutes (time needed for a proper diffusion of active components), the plates were incubated in normal atmosphere at $37^{\circ} \mathrm{C}$. After 24 hours of incubation, the inhibition zone diameters (in millimeters) were read and noted in spreadsheet software, aside the average price in $€ / \mathrm{ml}$ of essential oil. A cost-efficiency antibacterial activity index was also calculated, in order to offer a proper view on the quality-price relation regarding the antibacterial effect, using the formula:

$$
\text { index }=\frac{\text { price (euro) }}{\text { effect }(\text { diameter in } \mathrm{mm})}
$$

When the diameter exceeded $40 \mathrm{~mm}$, the index was calculated using this maximum readable value. The lower the index, the cost-efficiency is better.

\section{RESULTS}

By following the official reports on the chemical composition of EO by GC/MS analysis, we identified the major components which are presented in table no. 2. Small variances were found between the same constituents of the EO of the two producers.

Table no. 2. GC/MS analysis of EO of Pipper nigrum, Cinnamomum zeylanicum, Coriandrum sativum, Origanum vulgare

\begin{tabular}{|l|r|r|}
\hline Pipper nigrum & Producer A & \multicolumn{1}{|c|}{ Producer B } \\
\hline limonene & $23.35 \%$ & $19.15 \%$ \\
\hline beta-caryophyllene & $16.81 \%$ & $15.93 \%$ \\
\hline delta-3-carene & $15.56 \%$ & $12.82 \%$ \\
\hline alpha-pinene & $15.49 \%$ & $14.79 \%$ \\
\hline beta-pinene & $14.89 \%$ & $13.17 \%$ \\
\hline & $86.1 \%$ & $75.86 \%$ \\
\hline Cinnamomum zeylanicum & Producer A & Producer B \\
\hline trans-cinnamaldehyde & $59.01 \%$ & $52.82 \%$ \\
\hline trans-cinnamyl acetate & $7.55 \%$ & $10.94 \%$ \\
\hline beta-caryophyllene & $5.53 \%$ & $3.39 \%$ \\
\hline eugenol & $3.97 \%$ & $3.1 \%$ \\
\hline linalool & $2.17 \%$ & $2.4 \%$ \\
\hline camphor & $1.76 \%$ & $0.99 \%$ \\
\hline & $79.99 \%$ & $73.64 \%$ \\
\hline Coriandrum sativum & Producer A & Producer B \\
\hline linalool & $77.47 \%$ & $75.11 \%$ \\
\hline geranyl acetate & $3.79 \%$ & $1.44 \%$ \\
\hline camphor & $3.28 \%$ & $4.5 \%$ \\
\hline alpha-pinene & $4.97 \%$ & $0.48 \%$ \\
\hline
\end{tabular}

AMT, vol. 25, no. 3, 2020, p. 52 
CLINICAL ASPECTS

\begin{tabular}{|l|r|r|}
\hline gamma-terpinene & $3.47 \%$ & $4.53 \%$ \\
\hline & $92.98 \%$ & $86.06 \%$ \\
\hline Origanum vulgare & Producer $\mathbf{A}$ & Producer B \\
\hline carvacrol & $71.99 \%$ & $70.6 \%$ \\
\hline beta-bisabolene & $2.07 \%$ & $0 \%$ \\
\hline thymol & $1.55 \%$ & $3.8 \%$ \\
\hline gamma-terpinene & $4.11 \%$ & $6.19 \%$ \\
\hline para-cymene & $3.48 \%$ & $8.53 \%$ \\
\hline & $83.2 \%$ & $89.12 \%$ \\
\hline
\end{tabular}

Table no. 3 presents the antibacterial efficacy of all oils studied from both producers. All the EO from the Producer A managed to successfully inhibit $S$. mutans growth. With regard to EO from Producer A, the inhibition zone against $E$. faecalis ranged from the weakest $14 \mathrm{~mm}$ ( Black pepper), $28 \mathrm{~mm}$ (Coriander) to the strongest over $40 \mathrm{~mm}$ (Oregano and Cinnamon). With regard to volatile essential oils from Producer $\mathrm{B}$, against $E$. faecalis, the smallest inhibition zone was observed for Coriander $(10 \mathrm{~mm})$, followed by Black pepper $(11 \mathrm{~mm})$; on the opposite side, the strongest inhibition zone presented both Oregano EO and Cinnamon EO (34 mm). Against $S$. mutans, the weakest inhibition zone showed Black pepper $(6 \mathrm{~mm})$, followed by Coriander EO $(12 \mathrm{~mm})$ and the strongest inhibition zone had Oregano EO $(38 \mathrm{~mm})$ and Cinnamon EO $(40 \mathrm{~mm})$. Intense hemolysis has also observed for all EO from producer $\mathrm{A}$, and for Oregano EO and Cinnamon EO from producer B (figure no. 1).

\section{Figure no. 1. Inhibition zone of the essential oils}

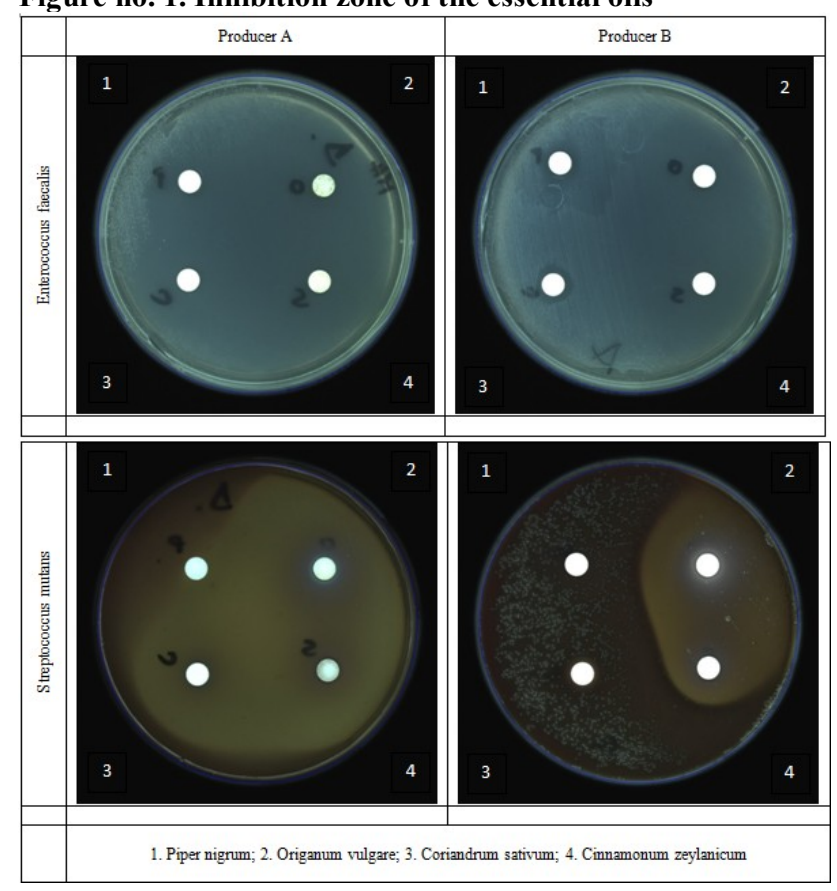

Table no. 3. Antibacterial effects of the tested essential oils on $E$. faecalis and $S$. mutans and the cost-efficiency antibacterial activity index

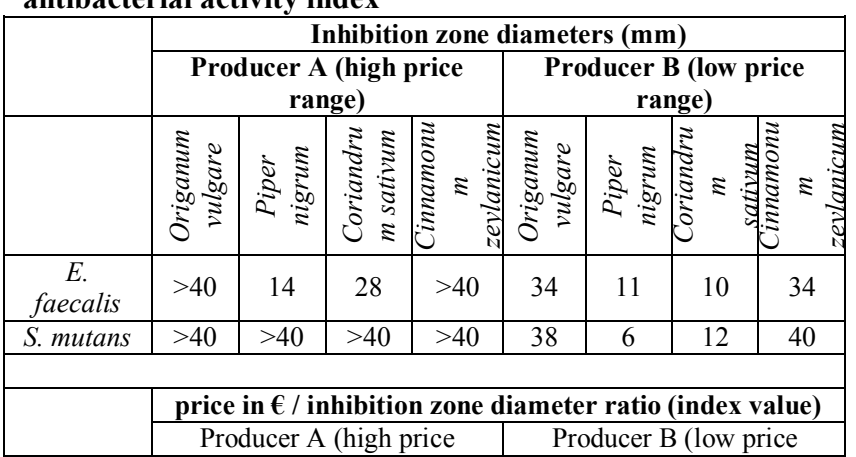

\begin{tabular}{|c|c|c|c|c|c|c|c|c|}
\hline & \multicolumn{5}{|c|}{ range) } & \multicolumn{4}{c|}{ range } \\
\hline $\begin{array}{c}\text { E. } \\
\text { faecalis }\end{array}$ & 0.06 & 0.39 & 0.08 & 0.14 & $\begin{array}{c}0.0 \\
3\end{array}$ & 0.13 & 0.12 & 0.04 \\
\hline S. mutans & 0.07 & 0.13 & 0.05 & 0.14 & $\begin{array}{c}0.0 \\
3\end{array}$ & 0.23 & 0.10 & 0.04 \\
\hline
\end{tabular}

The prices for $1 \mathrm{ml}$ of each oil from Producer A varied between 2,27-5,70 €/ml and those of Producer B varied between $1,18-1.68 € / \mathrm{ml}$. As presented in table no. 3, the obtained indices (price ratio / inhibition zone diameter) of each essential oil, both from Producer A and Producer B, were compared.

In both producers, Origanum vulgare $\mathrm{EO}$ was the most cost-efficient against $E$. faecalis (index $=0.06$ for Producer $A$ and 0.03 for Producer B). In the case of Producer A, against S.mutans the best index was seen at Coriandrum sativum EO $(0,05)$ and the weakest at Cinnamonum zeylanicum $(0,14)$. In the case of Producer B, against $E$. faecalis, the lowest index was seen at Piper nigrum $(0,13)$. The same pattern was seen against $S$. mutans, the highest index had Origanum vulgare $(0,03)$ and the lowest Piper nigrum $(0,23)$.

\section{DISCUSSIONS}

The aim of this work was to evaluate the antimicrobial capacity of some essential oils against an oral $S$. mutans and $E$. faecalis, which are responsable for different oral inflamations. The study showed that from all the low price EO tested against $S$. mutans, the highest effect had Cinnamon EO $(40 \mathrm{~mm}$ diameter) and the lowest had Black pepper EO $(6 \mathrm{~mm})$. Also, our results revealed that all the high price EO showed excellent antibacterial effect against the $S$. mutans $(>40 \mathrm{~mm}$ inhibition diameter). A similar study involving the effect of Cinnamomum zeylanicum EO against some gram positive and negative bacteria was carried by Al-fekaiki et al., and their inhibition diameter was less than ours, and ranged from 17.00$30.30 \mathrm{~mm}$.(28) Although the antibacterial effect of Oregano EO from the Producer A against $E$. faecalis is the most intense ( $>40$ $\mathrm{mm}$ ) of all studied oils, the cost-efficiency antibacterial activity index was not so good $(0,06)$ compared to the same oil $(0,03)$ from the Producer B, because it has a price three times higher. Similarly, even if the Cinnamon EO from the Producer A had a very strong antibacterial effect against E.faecalis $(>40 \mathrm{~mm})$ compared to the same EO of the producer B $(34 \mathrm{~mm})$, the costefficiency antibacterial activity index of Producer A was less $(0,14)$ than the index of Producer B $(0,04)$ because of the big price difference. The antibacterial effect of cinnamon may be explained due to its cinnamic aldehyde and eugenol compounds. Against group D streptoccocus, a previous study showed that Cinnamomum zeylanicum EO had an inhibitory effect, where the inhibition diameter was $26 \mathrm{~mm}$, even was less than in our study.(29) The antimicrobial activity of Cinnamomum zeylanicum and Black pepper was tested against S.mutans in a previous study which reported an $32.17 \pm 1.32 \mathrm{~mm}$ inhibition zone for $\mathrm{C}$ zeylanicum and $14.00 \pm 0.63$ for Black pepper, a weaker effect in comparison with our obtained effects.(30) P.V. Karsha et al. in their study revealed that Black pepper EO had a very good inhibitory effect on the growth of of Gram positive bacteria like Staphylococcus aureus, Bacillus cereus and E.faecalis as the Black pepper altered the membrane permeability.(31) As presented in table no. 3, in case of Coriander EO from the Producer A, we noticed an $28 \mathrm{~mm}$ inhibition zone against $E$. faecalis as well as a better value for the cost-efficiency antibacterial activity index $(0,08)$ than the effect of the same EO $(10 \mathrm{~mm})$ and the index $(0,12)$ from the Producer B, due also because of the small price difference between the two producers.

This study reveals that the Black pepper EO of Producer A presented a much better effect against $S$. mutans $(>$ $40 \mathrm{~mm})$ than the same EO $(6 \mathrm{~mm})$ of Producer B, and also 


\section{CLINICAL ASPECTS}

showed a better index $(0,13$ for producer A vs 0.23 for Producer B). According to the results of a previous study, the antimicrobial effect of Origanum vulgare EO against Streptococcus epidermidis was noticed using a disc diffusion assay, and was reported a $37 \mathrm{~mm}$ inhibition diameter.(32) Carvacrol and thymol, which are the main constituents of Oregano EO, are able to alter the permeability of the cell membrane that cause the death of the bacterial cells.(33) Hilal Yildiz (34) reported that the Coriandrum sativum EO inhibited a large spectrum of bacterias such as E.faecalis (with inhibition diameter $11 \mathrm{~mm}+-0,60$, Str.pyogenes (inhibition diameter 26 $\mathrm{mm})$ which is nearly in harmony to our low-price EO results against the $S$. mutans $(12 \mathrm{~mm})$ and $E$. faecalis $(10 \mathrm{~mm})$. In this current study we noticed that from the all low-price EO tested against E. faecalis, the lowest effect had Coriandrum sativum $(10 \mathrm{~mm})$ and the highest antibacterial effect had Oregano and Cinnamon $(34 \mathrm{~mm})$. Also, this study demonstrates that from the all high- price EO tested against E. faecalis the lowest effect was seen in Black Pepper $(14 \mathrm{~mm})$ and the highest in Oregano and Cinnamon $>40 \mathrm{~mm})$. Our results confirm that although the antibacterial effect of Cinnamon EO against S.mutans is nearly the same for both producers ( A-> $40 \mathrm{~mm}$ and B- $40 \mathrm{~mm}$ ) the cost-efficiency antibacterial activity index is better in Producer B $(0,04)$ than in Producer A $(0,14)$ due to the price advantage. While there is a very small difference between the Inhibition zone diameters of both Oregano EO tested against $S$. mutans in favor of Producer A , the cost-efficiency antibacterial activity index is in favor of Producer B (index 0,03) due to the price difference.

Goñi et al. reported in a previous study that the vapour phase of a combination of Cinnamon and Clove EO had an inhibition diameter of $17+-1 \mathrm{~mm}$ against $E$. faecalis, less than our results presented in our study. The chemical constituents of EO are hydrophobic and the bacterial cell membrane can accumulate these constituents leading to structural damages.(35) According to Melo et al. (36), E. faecalis was sensitive by the disc diffusion method to Oregano EO where the inhibition zone in $\mathrm{mm}$ ranged from $31,8+/-1,01$, nearly the same result we obtained with Oregano EO from the Producer B. As we can see in Table 3 the antibacterial effect of Black pepper EO against $E$. faecalis was weak (11-14 mm inhibition zone) but is in harmony with the findings of a similar study about the antimicrobial effect of the pepper oleoresin from Vietnam (9-10 mm Inhibition Zones).(10)

\section{CONCLUSIONS}

1. Most of essential oils studied from both Producers, had better antibacterial effect against $\mathrm{S}$. mutans compared to $\mathrm{E}$. faecalis.

2. All the EO from the Producer A managed to successfully inhibit $\mathrm{S}$. mutans growth.

3. The high price EO had a better antimicrobial effect compared to the low price EO.

4. The strongest antimicrobial effect against E.faecalis had the high- price Oregano and Cinnamon EO and the weakest antimicrobial effect had low- price Coriander EO.

5. Against S. mutans, the greatest efficacy had all high-price EO, and the lowest had the low-price Black pepper EO.

6. The high price of some EO (Piper nigrum) does not make any difference regarding the antibacterial effect. Lower price EO may be still suitable in regards of antibacterial effect if considering the associated costs, even if the effect does not reach the potency of the higher-price alternatives.

\section{REFERENCES}

1. Man A, Santacroce L, Jacob R, Mare A, Man L. Antimicrobial Activity of Six Essential Oils Against a
Group of Human Pathogens: A Comparative Study. Pathogens. 2019;8(3):108. doi:10.3390/pathogens8010015.

2. Tongnuanchan P, Benjakul S. Essential oils: Extraction, bioactivities, and their uses for food preservation. J Food Sci. 2014;9:R1231-R1249. doi: 10.1111/1750-3841.12492.

3. Puškárová $A$, Bučková $M$, Kraková L, Pangallo D, Kozics $\mathrm{K}$. The antibacterial and antifungal activity of six essential oils and their cyto/genotoxicity to human HEL 12469 cells. Sci Rep. 2017;7(1):8211. doi:10.1038/s41598-01708673-9.

4. Burt S. Essential oils: their antibacterial properties and potential applications in foods a review. Int $\mathrm{J}$ Food Microbiol. 2004;94:223-53.

5. Kalemba D, Kunicka A. Antibacterial and antifungal properties of essential oils. Curr Med Chem. 2003;10:813829 .

6. Lu M, Dai T, Murray CK, Wu MX. Bactericidal Property of Oregano Oil Against Multidrug-Resistant Clinical Isolates. Front Microbiol. 2018;9:2329. doi:10.3389/fmicb.2018.02329.

7. Yan F, Azizi A, Janke S, Schwarz M, Zeller S, Honermeier B. Antioxidant capacity variation in the oregano (Origanum vulgare L.) collection of the German National Genebank. Ind Crops Prod. 2016;92:19-25. doi: 10.1016/j.indcrop.2016.07.038.

8. Akgul A, Kivanc M. Inhibitory effects of selected Turkish spices and oregano components on some foodborne fungi. Int J Food Microbiol. 1988;6:263-268. doi: 10.1016/0168-1605(88)90019-0.

9. Morshed S, Hossain M, Ahmad M, Junayed M. Physicochemical Characteristics of Essential Oil of Black Pepper (Piper nigrum) Cultivated in Chittagong, Bangladesh. J Food Qual. Hazards Control. 2017;4 (3):6669.

10. Tran TH, Ke Ha L, Nguyen DC, Dao TP, Thi Hong Nhan L, Nguyen D, Nguyen TD, N. Vo, D.-V., Tran QT, Bach LG. The Study on Extraction Process and Analysis of Components in Essential Oils of Black Pepper (Piper nigrum L.) Seeds Harvested in Gia Lai Province, Vietnam. Processes 2019;7: 56

11. Nejad Ebrahimi S, Hadian J, Ranjbar H. Essential oil compositions of different accessions of Coriandrum sativum L. from Iran. Nat Prod Res. 2010;24(14):1287-1294. doi:10.1080/14786410903132316.

12. Zargari A. Medicinal plants. 5th ed. Vol. 2. Tehran University Publications; 1991. p. 1-942.

13. Han X, Parker TL. Antiinflammatory Activity of Cinnamon (Cinnamomum zeylanicum) Bark Essential Oil in a Human Skin Disease Model. Phytother Res. 2017;31(7):1034-1038. doi:10.1002/ptr.5822

14. Bardají DKR, Reis EB, Medeiros TCT, Lucarini R, Crotti AEM, Martins CHG. Antibacterial activity of commercially available plant-derived essential oils against oral pathogenic bacteria. Nat Prod Res. 2016;30: 11781181.

15. Yang XQ, Zheng H, Ye Q, Li RY, Chen Y. 2015. Essential oil of cinnamon exerts anti-cancer activity against head and neck squamous cell carcinoma via attenuating epidermal growth factor receptor - tyrosine kinase. J BUON 2015;20(6):1518-25

16. Anderson RA, Qin B, Canini F, Poulet L, Roussel AM. Cinnamon counteracts the negative effects of a high fat/high fructose diet on behavior, brain insulin signaling and Alzheimer-associated changes. PLoS One. 2013;8(12):e83243.

17. Aminzare M, Aliakbarlu J, Tajik H. The effect of Cinnamomum zeylanicum essential oil on chemical 


\section{CLINICAL ASPECTS}

characteristics of Lyoner- type sausage during refrigerated storage. Vet Res Forum. 2015;6(1):31-39.

18. Chericoni S, Prieto JM, Iacopini P, Cioni P, Morelli I. In vitro activity of the essential oil of Cinnamomum zeylanicum and eugenol in peroxynitrite-induced oxidative processes. J Agric Food Chem. 2005; 53(12):4762-4765. doi:10.1021/jf050183e

19. Komiyama EY, Lepesqueur LS, Yassuda CG, et al Enterococcus Species in the Oral Cavity: Prevalence, Virulence Factors and Antimicrobial Susceptibility. PLoS One. 2016; 11(9):e0163001. doi:10.1371/journal.pone.0163001.

20. Wang QQ, Zhang CF, Chu CH, Zhu XF. Prevalence of Enterococcus faecalis in saliva and filled root canals of teeth associated with apical periodontitis. Int J Oral Sci. 2012;4(1):19-23. doi:10.1038/ijos.2012.17.

21. Holbrook WP, Magnúsdóttir MO. Studies on strains of Streptococcus mutans isolated from caries-active and caries-free individuals in Iceland. J Oral Microbiol. 2012; 4:10.3402/jom.v4i0.10611. doi:10.3402/jom.v4i0.10611.

22. Galvão LC, Furletti VF, Bersan SM, et al. Antimicrobial Activity of Essential Oils against Streptococcus mutans and their Antiproliferative Effects. Evid Based Complement Alternat Med. 2012;2012:751435. doi: $10.1155 / 2012 / 751435$.

23. Choi O, Cho SK, Kim J, Park CG, Kim J. In vitro antibacterial activity and major bioactive components of Cinnamomum verum essential oils against cariogenic bacteria, Streptococcus mutans and Streptococcus sobrinus. Asian Pacific Journal of Tropical Biomedicine. 2016;6(4):308-314.

24. Li Y, Tanner A. Effect of antimicrobial interventions on the oral microbiota associated with early childhood caries. Pediatr Dent. 2015;37 (3):226-244.

25. Pinar Erdem A, Sepet E, Kulekci G, Trosola SC, Guven Y. Effects of two fluoride varnishes and one fluoride/chlorhexidine varnish on Streptococcus mutans and Streptococcus sobrinus biofilm formation in vitro. Int J Med Sci. 2012;9(2):129-136. doi:10.7150/ijms.3637.

26. Yousefimanesh H, Amin M, Robati M, Goodarzi H, Otoufi M. Comparison of the Antibacterial Properties of Three Mouthwashes Containing Chlorhexidine Against Oral Microbial Plaques: An in vitro Study. Jundishapur J Microbiol. 2015;8(2):e17341.

27. Benbelaïd F, Khadir A, Abdoune MA, Bendahou M, Muselli A, Costa J. Antimicrobial activity of some essential oils against oral multidrug-resistant Enterococcus faecalis in both planktonic and biofilm state. Asian Pac J Trop Biomed.

2014;4(6):463-472 doi:10.12980/APJTB.4.2014C1203.

28. Al-fekaiki DF, Niamah AK, Al-Sahlany STG. Extraction and identification of essential oil from Cinnamomum Zeylanicum barks and study the antibacterial activity. J Microbiol Biotech Food Sci. 2017/18;7(3) 312-316.

29. Oulkheir S, Aghrouch M, El Mourabit F, Dalha F, Graich H, Amouch F, Ouzaid K, Moukale A, Chadli S. Antibacterial Activity of Essential Oils Extracts from Cinnamon, Thyme, Clove and Geranium Against a Gram Negative and Gram Positive Pathogenic Bacteria. Journal of Diseases and Medicinal Plants. 2017;3(2-1): 1-5. doi: $10.11648 /$ j.jdmp.s.2017030201.11.

30. Wiwattanarattanabut $\mathrm{K}$, Choonharuangdej S, Srithavaj T In Vitro Anti-Cariogenic Plaque Effects of Essential Oils Extracted from Culinary Herbs. J Clin Diagn Res. 2017;11(9):DC30-DC35. doi:10.7860/JCDR/2017/28327.10668.

31. Karsha PV, Lakshmi OB. Antibacterial activity of black pepper (Piper nigrum Linn.) with special reference to its mode of action on bacteria. Indian Journal of Natural Products and Resources. 2010;1(2):213-215

32. Kulaksiz B, Er S, Üstündağ-Okur N, Saltan-Ișcan G. Investigation of Antimicrobial Activities of Some Herbs Containing Essential Oils and Their Mouthwash Formulations. Turk J Pharm Sci. 2018;15(3):370-375. doi:10.4274/tjps.37132.

33. Ben Arfa A, Combes S, Preziosi-Belloy L, Gontard N, Chalier P. Antimicrobial activity of carvacrol related to its chemical structure, Lett. Appl. Microbiol. 2006;43:149154

34. Yildiz H. Chemical Composition, Antimicrobial, and Antioxidant Activities of Essential Oil and Ethanol Extract of Coriandrum sativum L. Leaves from Turkey . International Journal of Food Properties. 2016;19:15931603.

35. Goñi P, López P, Sánchez C, Gómez-Lus R, Becerril R, Nerín C. Antimicrobial activity in the vapour phase of a combination of cinnamon and clove essential oils. Food Chemistry. 2009;116(4):982-989.

36. Melo AD, Amaral AF, Schaefer G, et al. Antimicrobial effect against different bacterial strains and bacterial adaptation to essential oils used as feed additives. Can J Vet Res. 2015;79(4):285-289. 